\title{
Developing a training tool for beginner athletes in woodball
}

\author{
S. M. Fernanda Iragraha \\ Program Studi Pendidikan Olahraga dan Kesehatan, STKIP Agama Hindu Singaraja,

\section{Soegiyanto} \\ Program Pascasarjana Universitas Negeri Semarang, \\ Hari Setijono \\ Program Pascasarjana Universitas Negeri Surabaya,
}

$\&$

Sugiharto

Program Pascasarjana Universitas Negeri Semarang

\begin{abstract}
This research aimed to produce models of hitting practice tools, which could be used in training beginner woodball athletes in Indonesia. A process of research and development was followed after the model of Gall, Gall, \& Borg (2007). Small-scale field trials were first conducted at Gerokgak Woodball Club (GWC), or Gerokgak Woodball Club (GWC) Buleleng-Bali, involving 10 athletes (5 males and 5 females). These were followed by large-scale field trials conducted in Pengkab Woodball Buleleng, or Pengkab Woodball Buleleng-Bali, involving 20 athletes (10 males and 10 females). Data gathered were both quantitative and qualitative. Quantitative descriptive analysis was employed with the (a) observation instruments/observations of the effectiveness of the tool development model; and (b) the athlete response questionnaire as part of the validation process. Qualitative descriptive analysis was applied to data gained from interviews, observations and fieldnotes in processing suggestions for improvement from material experts, media experts, and practitioners. This research produced an effective and appropriate hitting practice tool for beginners in woodball and a guide/instruction on how to use the tool. These wood practice products can be carried or moved in accordance with training needs (portable), can be used to train the consistency of the punch, increase the frequency of hitting exercises, in the open field (outdoor) or in the building (indoor). The wood practice tool can be used by athletes to practice short stroke, medium, long, or finishing/gating.
\end{abstract}

Keywords: woodball, development, practice, hitting, sport

\section{Please cite this article as follows:}

Iragraha, S. M. I., Soegiyanto, Setijono, H., \& Sugiharto (2020). Developing a training tool for beginner athletes in woodball. International Sports Studies, 42(e), 50-61 doi: $10.30819 /$ iss.42-1.06 


\section{Introduction}

Woodball is a game that can be played in a green environment. It is consistent with Olympic values, and can be played by everyone, regardless of age and gender (International Woodball Federation, 2020). Woodball is a game where you play against yourself (Iragraha, 2017, p. 890). This reflects the key philosophy of the sport of woodball which is very different from that of other sports such as badminton, volleyball, basketball, table tennis, and boxing. In all of these examples athletes are required to beat their opponents whereas in woodball it is different. Woodball is a sport that embraces a 'gentler' philosophy of competition which focuses more on the player and his personal struggle against himself.

Woodball was invented in 1990 by Mr. Ming-Hui Weng. He wanted to build a garden for his father to take a walk in and enjoy the beautiful view in the scenic spot of Nei-Shuang-His, situated in Shih-lin, Taipei City. After mowing the weeds that were on the hillside, he found that there were terraced fields beneath them which could be developed as an outdoor place of exercise. It came into his mind that he could make good use of this garden by designing it as a place for ball games. With this motive, he tried to create a ball sport, in which the ball would not fly up into the air (i.e. it could be played on the grass). Also, it should be economic (neither expensive to play nor requiring a large area), so that he could invite a number of friends to enjoy the fun of playing in the green field. After two years of experiment and modifications, the equipment and the rules of the game that finally emerged became known as woodball. The game is popular today among people of all ages. It has well-designed equipment, which includes ball, mallet and gate, and is easy to learn and to play. Woodball has today been adopted by the physical education courses in some colleges after it began to be introduced and developed into other countries (http://www.iwbf-woodball.org/en/11.php).

Woodball was first introduced and developed in Indonesia in 2006. It was registered with the Indonesian National Sports Committee (KONI), with number: 2751/LNG/X/06 on 4 October following the establishment of the Indonesia Woodball Association, (IWbA) on October 1. It was subsequently recommended that the sport of woodball be included in the $1^{\text {st }}$ Asean Beach Games 2008 in Bali.

Woodball is an outdoor game that can be played on grassy fields and on the beach (beach woodball). The types of competition used in woodball games are: (1) singles competition (2) doubles competition - same sex or mixed and (3) teams competition with a team consisting of between four and six players. There are two types of competitions in Woodball. These are a stroke based competition, where the competitor who completed twelve fairways or its multiple fairways with the lowest strokes shall be the winner; and (2) a fairway based competition, where the competitor who had won the greater number out of the twelve fairways (or its multiple fairways) with the lowest strokes shall be the winner (http://www.iwbf-woodball.org/en/2-1.php).

The techniques used in woodball are similar to the techniques used in the sport of golf. There are two basic techniques, namely those without tools and those with tools. Techniques without tools include set-up (preparation), routine pre-swing (wagle) without tools, and swinging movements. While techniques with tools include pre-swing routines (wagle) with mallets, long distance hit, medium range hit, short range hit, and hit to the gate (gating). Some of the terms have been adopted from golf such as - course, fairway, par, and gate-in-one (after hole-in-one). A very basic difference between golf and woodball is to be found in the equipment. The striking implement is a mallet (wooden bat) rather than a club or iron. The target is a gate rather than a hole. Also, in 
woodball there is only one ball used during the game (except if there is a broken ball, which can be replaced with the permission of the referee or the race supervisor). The equipment used namely the mallet, ball, and gate are mostly made of wood. However more recently, there has been a change to using aluminum materials (especially for the mallet and gate).

Iragraha (2017) highlighted that a very interesting characteristic of woodball is that it can involve the three basic concepts of motion: (1) locomotor motion or the movement of the body from one point to another - as when the game progresses from one fairway to another fairway; (2) non-locomotor motion - as when practising by bending and swinging the mallet, and; (3) manipulative motion, or the coordination of the body, space, and objects around it - as when the athletes swing the mallet to hit the ball toward the target or gate. The game also considers the elements of efficiency (time, place, and cost) in its activities, is environmentally friendly and supports humans in their need for physical activity.

There have been a number of notable achievements by Indonesian woodball athletes. Ahris Sumariyanto, Indonesia's best male woodball athlete, was ranked number one in the world in 2012. He also won a gold medal at the 2016 Asian Beach Games (Danang, Vietnam), and recaptured his number one world ranking in 2016, 2017 and 2018. Up until the present, especially in the adult category, athletes from Banten Province, Central Java Province, and Bali Province have been the most successful at national and international levels. These include Ahris Sumariyanto, Ahmad Faqih, Ika Yulianingsih, Muhamad Khadiq, Kadek Agus, and Putu Budhiyasa. Their achievements have not been matched at the novice level (juniors). This has been due to the focus of the coaching and the practice of sending senior athletes only to various training/events. Little attention has been paid to the beginning athletes who have been further hampered by limited facilities and infrastructure, the lack of technique and poor management. There are however some areas that already have permanent fields such as SlemanYogyakarta and Buleleng-Bali, yet their starter athletes have also failed to show significant achievements at national or international woodball events.

The results of interviews and observations conducted by researchers in Sleman, Yogyakarta and in the Regency of Buleleng, Bali, revealed some of the problems experienced by these novice athletes, namely: (1) a lack of mastery of woodball playing techniques (ranging from how to hold a bat or mallet, making preparations or settingup, the swing to hitting the ball and the follow through); (2) a lack of confidence in hitting the ball (which can be seen from the length of time the athlete takes to make the hit movement which is often more than ten seconds); (3) nervousness about the outcome; (4) a lack of ability in understanding the character of the field (this is marked by the number of balls that go outside the track or fairway when athletes practice hitting); (5) poor practice methods - the exercise done by the athlete seems to be very ineffective, such as in using just one ball for batting practice; and (6) a lack of tools and equipment to facilitate the training process.

Based on the problems mentioned above, efforts need to be made by researchers to deliver a training process that is effective and efficient (in terms of time, energy, and cost) for beginner athletes. Particularly there is a need to develop a hitting practice aid for beginners in woodball. So far there have been a swing training aid developed by Anas Kholikul Amin in 2017, tools for basic swing techniques (WoodSwing) developed by Ahris Sumaryanto in 2018, and a gating drill training aid developed by Wisnu Wicaksono in 2018. The research to date has resulted in woodball training aids that can be used as a means of practising movements, improving basic swing techniques, and training finishing/gating techniques for beginner and advanced level woodball athletes. 
From the observations made by researchers on the tools that have been previously developed, they are too cumbersome (the sizes are too large and difficult to move from place to place), they have not yet been able to be used by many athletes as they have not been mass produced, and they are not as effective in practice as they might be, because they can only develop swinging skills, rather than the ability to hit the ball for all stroke techniques.

Therefore, the ineffectiveness of the tools already developed, led researchers to seek to develop a new training aid for novice athletes in the sport of woodball.

\section{Method}

This research followed a research and development process to develop and validate a training aid for the sport of Woodball. It followed an approach described by authors such as Gall, Gall, \& Borg (2007), Maksum (2012) and Sugiyono (2010) in detailing the research and development process as an industry-based development model, in which research findings are used to design new products and procedures. These are then systematically field-tested, evaluated, and refined until they meet the specified criteria of effectiveness, quality, or similar standards.

The model outlined by Gall, Gall, \& Borg consists of ten steps, which are as follows:

1. Preliminary studies. A preliminary study for the purposes of research and information collecting was carried out by researchers through interviews with four coaches and six beginner athletes. Observations were made in Sleman RegencyYogyakarta involving seventeen athletes and in Buleleng Regency-Bali involving twent-two athletes. Various problems experienced by the athletes were noted during these observations.

2. Research planning. The second step involved planning for the research. This part of the process included: (a) identifying the existing needs and formulating the research objectives; (b) estimating the funds needed and the resources required in terms of manpower and time, and; (c) formulating the qualifications and roles of the researchers. 3. Development of the design. The third step involved developing the preliminary design of the product by: (a) determining the product design to be developed (hypothetical design); (b) determining the research facilities and infrastructure required during the research and development process; (c) determining the stages necessary for implementing the design test in the field; and (d) determining the job description of the parties involved in the research.

4. Preliminary field testing. The fourth step comprised a limited trial which was carried out at the Woodball Field at SPN POLDA Bali Singaraja, involving six athletes (three male and three female) from the Remaja Bhayangkara Club (RBC).

5. Main product revision This fifth step involved the improvement of the model or design, based on the findings of the preliminary field testing. Evaluations carried out during this stage included a limited testing of the product focusing on trialling and evaluating the training aids and the process of using them, and the consideration of suggestions for improvement made by experts. This process was internal to the research team and depended on the qualitative feedback provided by those involved.

6. Main field testing. The sixth step involved more extensive trials carried out at SMP $\mathrm{N} 1$ Gerokgak involving ten athletes (five male and five female) from the Gerokgak Woodball Club (GWC). 
7. Operational product revision. The seventh step was about improving the product from the results of this wider field test in order to further strengthen the product being developed. Systematic observations (see Table 1) and suggestions for improvements from the field trials were widely used by the research team as the basis for product improvements in preparation for larger scale trials.

Table 1

Observation instrument for Woodball experts, equipment experts, and practitioners

\begin{tabular}{|c|l|l|l|l|l|}
\hline Num. & \multicolumn{1}{|c|}{ Classification of Observations } & \multicolumn{3}{c|}{ Alternative Answers } \\
\cline { 3 - 6 } & & NS & SS & S & PS \\
\hline 1. & $\begin{array}{l}\text { The hitting practice tool matches the } \\
\text { characteristics of beginner athletes and the } \\
\text { characteristics of woodball. }\end{array}$ & & & & \\
\hline 2. & The hitting practice tool is easy to use. & & & & \\
\hline 3. & $\begin{array}{l}\text { The hitting practice tool can be used by both } \\
\text { male and female athletes. }\end{array}$ & & & & \\
\hline 4. & $\begin{array}{l}\text { The hitting practice tool attract athletes to } \\
\text { participate actively }\end{array}$ & & & & \\
\hline 5. & $\begin{array}{l}\text { The hitting practice tool can be used indoors } \\
\text { or outdoors. }\end{array}$ & & & & \\
\hline 6. & $\begin{array}{l}\text { The hitting practice tool can be used to } \\
\text { practice gating, short, medium and long } \\
\text { strokes. }\end{array}$ & & & & \\
\hline 7. & $\begin{array}{l}\text { The hitting practice tool can develop athletes' } \\
\text { abilities. }\end{array}$ & & & & \\
\hline 8. & The hitting practice tool is safe to use. & & & & \\
\hline 9. & $\begin{array}{l}\text { The hitting practice tool makes it easier for } \\
\text { coaches to monitor athletes who are practising. }\end{array}$ & & & & \\
\hline 10. & $\begin{array}{l}\text { There are innovations and new creations in } \\
\text { terms of training facilities for woodball. }\end{array}$ & & & & \\
\hline
\end{tabular}

$\mathrm{NS}=$ Not Suitable, score $=1 ; \mathrm{SS}=$ Sufficiently Suitable, score $=2 ; \mathrm{S}=$ Suitable, score $=3 ; \& \mathrm{PS}=$ Perfectly Suitable, score $=4$

8. Operational field testing. The eighth step was a large-scale trial, assessing the effectiveness and adaptability of the product design for use by product users and its readiness to be applied in a wide number of contexts. The trial was carried out at the SPN POLDA Bali Singaraja Woodball Field, involving twenty athletes (ten male and ten female) from the Pengkab Woodball Buleleng-Bali.

9. Final product revision. This ninth step is concerned with perfecting the product that has been developed. The results of the assessment and suggestions for improvements coming from the large-scale trial (see Table 2), as well as field notes, provided the material that identified any product revisions to be included in compiling the final product, namely a hitting practice tool for beginner athletes in Woodball that is effective, efficient, and suitable for training. At this stage the effectiveness of the product that had been produced was confirmed and validated. 
Table 2

Athletes' responses to the effectiveness of the hitting practice tool model

\begin{tabular}{|c|l|l|l|l|l|}
\hline Num. & \multicolumn{1}{|c|}{ Classification of Observations } & \multicolumn{3}{c|}{ Alternative Answers } \\
\cline { 3 - 5 } & & NS & SS & S & PS \\
\hline 1. & The hitting practice tool is comfortable to use. & & & & \\
\hline 2. & $\begin{array}{l}\text { The hitting practice tool matches the } \\
\text { characteristics of woodball. }\end{array}$ & & & & \\
\hline 3. & $\begin{array}{l}\text { The hitting practice tool can be used by both } \\
\text { male and female athletes. }\end{array}$ & & & & \\
\hline 4. & $\begin{array}{l}\text { The hitting practice tool can increase interest } \\
\text { to continue practising. }\end{array}$ & & & & \\
\hline 5. & $\begin{array}{l}\text { The hitting practice tool can make training } \\
\text { efficient and effective }\end{array}$ & & & & \\
\hline 6. & $\begin{array}{l}\text { The hitting practice tool can be used indoors } \\
\text { or outdoors. }\end{array}$ & & & & \\
\hline 7. & $\begin{array}{l}\text { The hitting practice tool can be used to } \\
\text { practice gating, short, medium and long } \\
\text { strokes. }\end{array}$ & & & & \\
\hline 8. & The hitting practice tool is safe to use. & & & & \\
\hline 9. & $\begin{array}{l}\text { The hitting practice tool's feel' and } \\
\text { techniques. }\end{array}$ & & & & \\
\hline 10. & $\begin{array}{l}\text { The hitting practice tool's support for the } \\
\text { development and achievement of woodball } \\
\text { skills. }\end{array}$ & & & \\
\hline
\end{tabular}

Information

$\mathrm{NS}=$ Not Suitable, score $=1 ; \mathrm{SS}=$ Sufficiently Suitable, score $=2 ; \mathrm{S}=$ Suitable, score $=3 ; \& \mathrm{PS}=$ Perfectly Suitable, score $=4$

10. Implementation and dissemination. This tenth step requires that in conjunction with the production and distribution of the product the results of the research are presented in scientific forums and awareness of its existence is promoted in exhibitions during the ongoing woodball championships, or through the mass media.

Data used in this study were both quantitative and qualitative. Quantitative descriptive analysis was employed in the (a) observation instruments/observations of the effectiveness of the tool development model; and (b) the athlete response questionnaire. Whereas qualitative descriptive analysis was used to evaluate the suggestions for improvement from material experts, media experts, and practitioners as well as in field notes.

\section{Results}

The ten steps of the Gall, Gall, \& Borg development method can be operationally divided into 3 (three) stages, namely: (a) problem identification or needs analysis; (b) the development of designs and draft models and; (c) the testing phase (expert review, small-scale field trials, and large-scale field trials). 


\section{A. Needs analysis \\ 1) Preliminary studies}

The need to address gaps that were occurring in the development of novice athletes in the sport was first observed. Further research then identified that a major concern was the lack of availability of any effective and widely available training aids to help in developing hitting skills for beginners. Existing tools that had been developed in previous studies were then reviewed. These included the swing training aids developed by Anas Kholikul Amin in 2017, a basic swing technique training tool (Woodswing) developed by Ahris Sumaryanto in 2018, and a finishing/gating training tool developed by Wisnu Wicaksono in 2018, pictured in figure 1. A number of problems with them were noted for their use with both beginner and advanced woodball athletes. The size of the tools is too large, making it difficult for them to be moved from place to place. The tools, up until now, have not been available for use by woodball athletes and are not mass produced. They are not very effective for use in training, because they were only developed for swinging skills, rather than for hitting the ball in a real and direct way for all stroke techniques. There is a need for athletes to be able to practice using wood practice tools, by hitting directly and according to the actual techniques used in playing woodball.

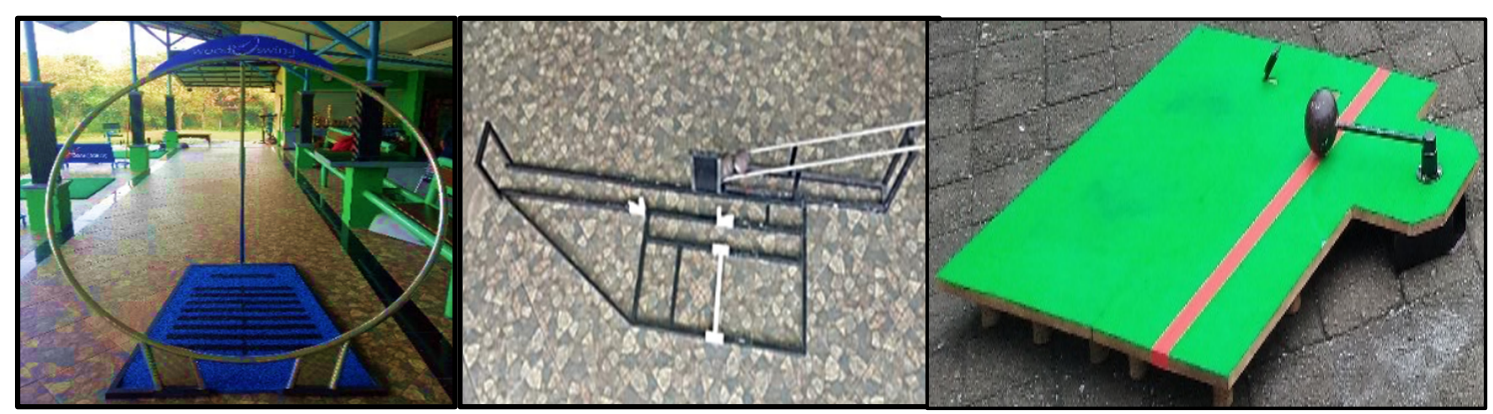

Figure 1. Some existing woodball tools.

\section{2) Research planning}

The next stage in the research identified the criteria which the tool would have to meet in order to be effective. It needed to be able to be easily carried or moved in accordance with training needs. It needed to develop consistency of the punch, allow for frequency of practice of the hitting exercises used in training, be capable of being used both in the open field (outdoors) or inside (indoors). It needed to be flexible enough to be used by athletes to practice short stroke, medium, long, or finishing/gating. Finally, there was a need to ensure the product was simple, safe, and economical. As such the materials used should be easy to obtain and the whole equipment easy to operate.

\section{B. Development of designs and draft models}

\section{3) Design development}

The next stage involved the preliminary development of the product. This part of the process involved the four stages of making product designs: making working drawings; preparing equipment and material requirements; the manufacture of components and parts needed; assembly. 


\section{4) Preliminary field testing}

Wood Practice tools were compiled/made with the help of technicians/mechanical engineering teachers from SMK N 3 Singaraja, Buleleng, Bali. After the draft practice training model (Wood Practice) had been completed, then its efficacy was discussed with the team of promoters, experts, and practitioners involved in this study to obtain suggestions and input as to any final improvements.

\section{The testing phase \\ 5) Limited product testing}

This phase produced a number of suggested improvements from material experts, media experts, practitioners and athletes. Firstly, tests were conducted on a flatter cement field, with the goal of making the practice tool more stable when used by athletes for batting practice. This led to further steps to increase its stability by replacing the base/ table stand legs with logs made around the base table and increasing the base area of the platform/table making it bigger/wider/heavier. It was noted that the ball stop brake was rather hard when stepped on, so the brake settings were loosened which enabled athletes to step easily on the brake pedal to stop the ball spinning.

\section{6) Main product revision}

In addition to the above outcomes from the product testing, as part of the main product revision the tool was reinforced with a key that fitted all the mechanics of the tool so that it would not sag. Some parts of the product were repainted to improve the appearance, and iron plates were added to strengthen the connection of the table runway to minimise unwanted movement. This stage then produced the final product in the form of a training aid for beginners in woodball.

\section{7) Main field test}

To be able to use the practice aid appropriately, athletes had first to know the guidelines for safety, the function of each component, and the overall workings of the tool. After these were known, then the tool could be used and tested in the field. The following are the procedures or ways to use the practice tool that were provided for the field and operational testing:

\section{How to use a Wood Practice Tool}

Male and female athletes are shown practising with the wood practice tool in figure 2. It shows that the wood practice tool is very practical as it can be used in various locations. By standing on the tool, an athlete can practice various types of stroke techniques (short, medium, long, or finishing/gating). It is easy for the trainer to provide direct feedback when the athlete is rehearsing his/her technique. 


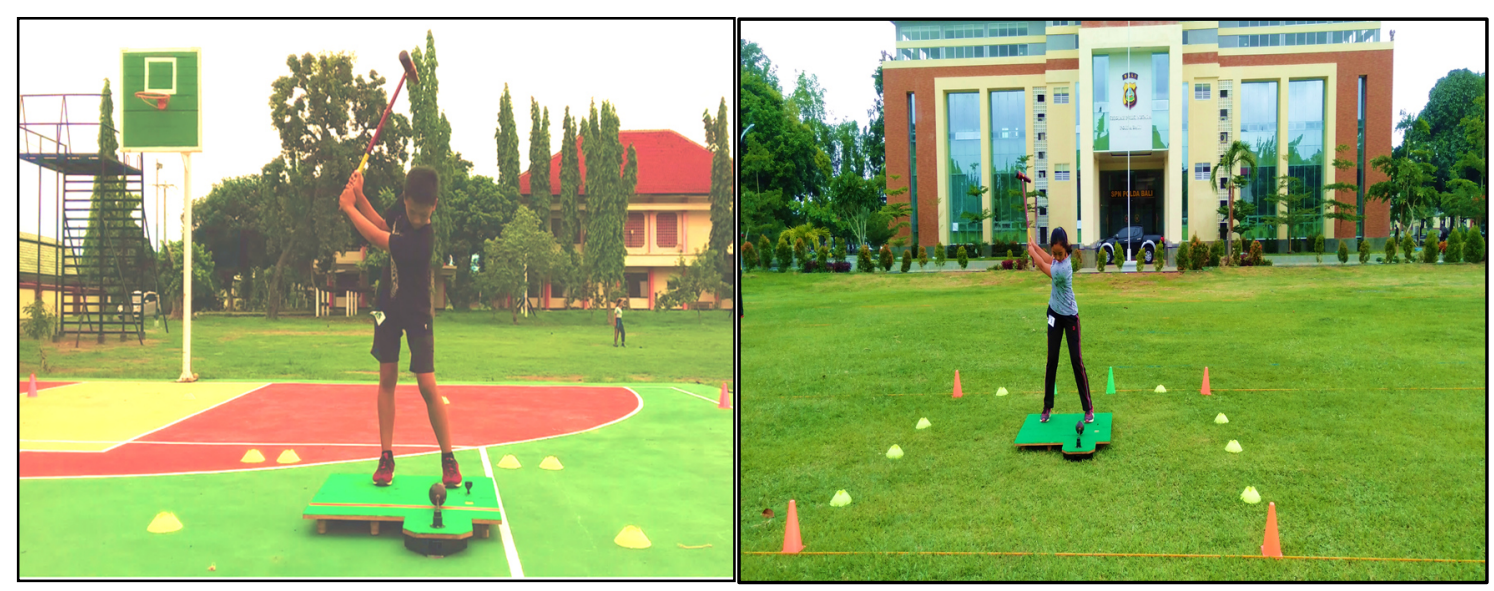

Figure 2. Male and female athletes practising with the wood practice tool.

1) The following guidelines should be applied to ensure athlete safety in using the wood practice tool, namely (a) the floor/field must be clear of harmful things; (b) information must be provided so that athletes understand how it should be used in training; (c) a companion should be present to supervise athletes during training; and (d) when athletes are practising, the area around the wood practice tool must be 1-2 metres clear of any crowd.

2) The athlete stands on the runway/table while carrying a bat (mallet).

3) The athlete assumes the training position to be performed.

4) Exercise time should be from 5-10 minutes.

5) Athletes can perform short, medium, long or finishing shots. During training, the position of the hitter's left foot should be straight and in line with the ball/shaft of the wood practice tool. The distance between the ball and the hitter is $\pm 25 \mathrm{~cm}$. which can be adjusted according to the technique and comfort of the hitter while doing the practice.

6) After the athlete has made a hit, let the ball spin for a moment, then step on the brake pedal slowly and repeatedly so that the ball does not stop immediately. When the ball has stopped, return the ball to its original place, and the athlete can repeat the exercise as needed.

7) This tool is easier to use for athletes who have a right-hand dominant hitting technique.

\section{8) Operational field testing}

Small scale (10 athletes) and large scale (20 athletes) field trials were held and resulted in a positive response to the model. The responses were interpreted as meaning that the wood practice tool was effective for the practice and training of a variety of stroke techniques. Further it could stimulate athletes' interest in training, was efficient in use of time, could be moved and used in various places. Most of all it helped develop the 'feeling' of hitting for athletes. It could contribute to the development of the sport of woodball.

\section{9) Final product revision}

The research and development process resulted in the final product of a training aid for beginner athletes in woodball. The process continued through several stages of field trials. Validation/assessment as well as suggestions were obtained from material experts, media experts, and practitioners. By the end the wood practice tool had 
undergone four revisions, namely: (1) before the initial product validation; (2) before small-scale field trials; (3) after small-scale field trials; and (4) after large-scale field trials.

\section{0) Dissemination and implementation}

The wood practice tool has been disseminated and exhibited during the KONI Cup Woodball Championship in Buleleng Regency in 2019.

\section{The results of expert validation and the test of the effectiveness of the Hitting Practice Tool}

A summary of the results obtained for the expert validation is presented in Table 3 broken down according to the area of expertise offered - woodball knowledge, equipment knowledge and training practice knowledge.

\section{Table 3}

Summary of results of the validation by woodball experts, equipment experts, and a woodball practitioner

\begin{tabular}{|c|c|c|c|c|c|c|c|c|c|c|c|c|}
\hline \multirow{3}{*}{$\begin{array}{l}\text { Validation } \\
\text { Code }\end{array}$} & \multirow{3}{*}{$\begin{array}{c}\text { Expert } \\
\text { Code }\end{array}$} & \multicolumn{10}{|c|}{ Item Classification } & \multirow[t]{3}{*}{ Total } \\
\hline & & 1 & 2 & 3 & 4 & 5 & 6 & 7 & 8 & 9 & 10 & \\
\hline & & \multicolumn{10}{|c|}{$\begin{array}{l}\text { Assessment Results from the Value } \\
\text { Scale }\end{array}$} & \\
\hline \multirow{4}{*}{ H1 } & $\mathrm{A} 1$ & 3 & 4 & 4 & 4 & 3 & 4 & 4 & 3 & 4 & 4 & 37 \\
\hline & A2 & 4 & 4 & 4 & 4 & 4 & 4 & 4 & 3 & 3 & 4 & 38 \\
\hline & A3 & 4 & 4 & 4 & 4 & 3 & 4 & 3 & 4 & 4 & 4 & 38 \\
\hline & $\mathrm{P} 1$ & 4 & 4 & 4 & 4 & 4 & 4 & 4 & 3 & 3 & 4 & 38 \\
\hline
\end{tabular}

Information:

H1= Observation Results of Training Aid Model Hitting for Beginners at Woodball; A1 \& A2 = Woodball Expert; A3 = Equipment Expert; \& P1= Practitioner/Trainer

These data provide statistical support for the conclusion of the experts that the training aid model is in the "good" category by: serving as an innovation for the sport of woodball; being easy to use; allowing for training in accordance with the characteristics of woodball sports; able to be used by both male and female athletes; safe and attractive for athletes; facilitating athletes in the training process; able to be used indoors and outdoors, and ; able to be used to train a variety of stroke techniques.

Table 4 similarly shows the results for the effectiveness of the tool. These include the results for the athletes involved in the operational field testing. 
Table 4

Observation results of the effectiveness of the Assistance Model Hitting Training and Athlete Response

\begin{tabular}{|c|c|c|c|c|c|c|c|c|c|c|c|c|}
\hline \multirow{3}{*}{$\begin{array}{l}\text { Validation } \\
\text { Code }\end{array}$} & \multirow{3}{*}{$\begin{array}{l}\text { Expert } \\
\text { Code }\end{array}$} & \multicolumn{10}{|c|}{ Item Classification } & \multirow{3}{*}{ Total } \\
\hline & & 1 & 2 & 3 & 4 & 5 & 6 & 7 & 8 & 9 & 10 & \\
\hline & & \multicolumn{10}{|c|}{$\begin{array}{c}\text { Assessment Results from the } \\
\text { Value Scale }\end{array}$} & \\
\hline \multirow{4}{*}{$\mathrm{H} 2$} & A1 & 4 & 3 & 4 & 4 & 4 & 4 & 4 & 3 & 4 & 4 & 38 \\
\hline & A2 & 4 & 4 & 4 & 3 & 4 & 3 & 4 & 3 & 4 & 4 & 37 \\
\hline & P1 & 4 & 3 & 4 & 4 & 4 & 4 & 4 & 3 & 4 & 4 & 38 \\
\hline & R1 & 3 & 4 & 4 & 3 & 4 & 3 & 3 & 4 & 4 & 4 & 36 \\
\hline
\end{tabular}

H2 = The Results of the Effectiveness of Hitting Training Aid Development;

A1 \& A2 = Woodball Expert; \& P1= Practitioner/Trainer; \& R1 = Athletes

\section{Conclusion}

The aim of this research was to develop a training aid for beginners in woodball. The method adopted the steps proposed by (Gall, Gall, \& Borg, 2007), as a means to create a product that would be recognized as feasible. The feasibility of this product was established from the point of view of material experts, media experts, practitioners, and woodball athletes as users.

The tool itself, since named Wood Practice can be summarised as having the following advantages and limitations.

Advantages The advantages of the product for the practice of hitting in woodball are it

(1) can be used to train a variety of punch techniques and can increase the frequency of athletes' hitting practice;

(2) can help athletes develop a 'feel' for hitting;

(3) assists efficiency in training by being economical in the use of time;

(4) is portable and can be used at various sites (grass or cement-lined fields);

(5) can be used by male and female athletes; and

(6) can be economically produced while being innovative in the benefits it brings

Limitations Its limitations which also need to be recognised include

(1) it was developed for use only with beginner athletes;

(2) it is easier to use for athletes who have a dominant right-hand hitting technique;

(3) it does not make use of modern technology but relies only on manual methods, and

(4) as such is capable of future improvement using more modern technology

\section{Acknowledgements}

Head of the LPDP dissertation scholarship from the Ministry of Finance of the Republic of Indonesia and all staff who have facilitated this research, Unnes dissertation promoter team and, all ranks of Buleleng-Bali woodball organisations and athletes. 


\section{References}

Amin, A. K., Doewes, M., \& Purnama, S. K. (2017). Development of prototype: a swinging training aid tool "Swing Trainer" on woodball male athletes. European Journal of Physical Education and Sport Science 3(4) 98-108. https://doi.org/10.5281/zenodo.546082

Azwar, S. (2014). Penyusunan Skala Psikologi. (edisi 2) Yogyakarta: Pustaka Pelajar.

Chang, S. H., \& Lee, J. (2017). Teaching striking skills in elementary physical education using woodball. Journal of Physical Education, Recreation \& Dance, 88(8), 21-27. https://doi.org/10.1080/07303084.2017.1356767

Dewi, P. C. P., \& Sukadiyanto, S. (2015). Pengembangan tes keterampilan olahraga woodball untuk pemula. Jurnal Keolahragaan, 3(2), 228-240.

Dick, W., Carey, L., \& Carey, J. O. (2009). The Systematic Design of Instruction (7th ed.). Columbus, Ohio: Merrill.

dan Kriswantoro, W. D. (2009). Olahraga Woodball. Malang: Wineka Media

Gall, M.D., Gall, J.P., \& Borg, W.R. (2007). Educational Research: An Introduction (8th ed.). New York: Pearson Education, Inc.

International Woodball Federation. (2014). "About IWbF: Philosophy; Courses; Equipment; Woodball rules and etc". Retrieved from http://www.iwbf-woodball.org/en/1-2.php. $1 / 09 / 2020$

Iragraha, F., Sugiharto, M., Soegiyanto, K. S., \& Setijono, H. (2018, December). The development of a hitting practice tool model on woodball. In 2nd Yogyakarta International Seminar on Health, Physical Education, and Sport Science YISHPESS 2018) and 1st Conference on Interdisciplinary Approach in Sports (CoIS 2018). Atlantis Press

Iragraha, S. F., Soegiyanto, S., Setijono, H., \& Sugiharto, S. (2019). Peran Media Massa dan Wanita dalam Olahraga Woodball. In Prosiding Seminar Nasional Pascasarjana (PROSNAMPAS) (Vol. 2, No. 1, pp. 981-991).

Iragraha, S. M. F., Soegiyanto, Setijono, H., \& Sugiharto. (2019b). The role of Woodball Sports organization Universitas Negeri Semarang (Unnes) in producing talented athletes. International Journal of Engineering and Advanced Technology, 9(2), 4928-4932. https://doi.org/10.35940/ijeat.b3308.129219.

Kriswantoro. (2015). Teknik Dasar Bermain Woodball. Semarang: Fastindo.

Lu, Y. C., \& Gu, Y. D. (2011). Evaluation of the mechanical performance of woodball mallet: a finite element study. Applied Mechanics and Materials, 80. 1032-1034. https://doi.org/10.4028/www.scientific.net/AMM.80-81.1032

Maksum, A. (2012). Metodologi Penelitian dalam Olahraga. Surabaya: Unesa University Press.

Sugiyono, S. (2010). Metode penelitian kuantitatif dan kualitatif dan R\&D. dan R \& D. Bandung: Alfabeta.

Sumariyanto, A., Rahayu, T., \& Sulaiman, S. (2018). The development of a woodball swing tool model for UNNES woodball students (Student Activity Units). Journal of Physical Education and Sports, 7(3), 242-245. https://journal.unnes.ac.id/sju/index.php/jpes/ article/ view/24891/11255.

Weng, M. H. (2008). President's Woodball Message: Competitive, Leisure, Health and Fun. Retieved from: http://www.iwbf-woodball.org

Wicaksono, W., Rahayu, T., \& Rumini, R. (2018). The development of gating drill tool of woodball sports branch on Central Java woodball athlete. Journal of Physical Education and Sports, 7(3), 246-249. 